FEDERAL RESERVE BANK OF SAN FRANCISCO

WORKING PAPER SERIES

\title{
Optimal Monetary Poilicy and Capital Account Restrictions in a Small Open Economy
}

\author{
Zheng Liu \\ Federal Reserve Bank of San Francisco \\ Mark M. Spiegel \\ Federal Reserve Bank of San Francisco
}

February 2015

Working Paper 2013-33

http://www.frbsf.org/publications/economics/papers/2013/wp2013-33.pdf

The views in this paper are solely the responsibility of the authors and should not be interpreted as reflecting the views of the Federal Reserve Bank of San Francisco or the Board of Governors of the Federal Reserve System. 


\title{
OPTIMAL MONETARY POLICY AND CAPITAL ACCOUNT RESTRICTIONS IN A SMALL OPEN ECONOMY
}

\author{
ZHENG LIU AND MARK M. SPIEGEL
}

\begin{abstract}
Declines in interest rates in advanced economies during the global financial crisis resulted in surges in capital flows to emerging market economies and triggered advocacy of capital control policies. We evaluate the effectiveness for macroeconomic stabilization and the welfare implications of the use of capital account policies in a monetary DSGE model of a small open economy. Our model features incomplete markets, imperfect asset substitutability, and nominal rigidities. In this environment, policymakers can respond to fluctuations in capital flows through capital account policies such as sterilized interventions and taxing capital inflows, in addition to conventional monetary policy. Our welfare analysis suggests that optimal sterilization and capital controls are complementary policies.
\end{abstract}

Date: February 23, 2015.

Key words and phrases. capital controls, sterilization, optimal policy, capital flows, open-economy. JEL classification: F31, F32, E42.

Liu: Federal Reserve Bank of San Francisco, 101 Market Street, San Francisco, CA 94105 (email: Zheng.Liu@sf.frb.org). Spiegel: Federal Reserve Bank of San Francisco, 101 Market Street, San Francisco, CA 94105 (email: Mark.Spiegel@sf.frb.org). We thank Olivier Blanchard, Pierre-Olivier Gourinchas, Young Sik Kim, seminar participants at the Federal Reserve Bank of San Francisco, the IMF-BOK conference on "Asia: Challenges of Stability and Growth," the Banque de France, the 7th Annual MIFN Conference, UC Santa Cruz, and an anonymous referee for helpful comments. The views expressed herein are those of the authors and do not necessarily reflect the views of the Federal Reserve Bank of San Francisco or the Federal Reserve System. 


\section{INTRODUCTION}

In the wake of the recent global financial crisis, central banks in advanced economies reduced global interest rates dramatically. Small open economies that were perceived as having desirable growth prospects experienced surges of foreign capital inflows [e.g. Ghosh et al. (2014)]. Many commentators argue that these capital inflows associated with easy monetary policies in advanced economies posed potential threats to emerging market economies by pushing up inflation. Moreover, sudden reversals in capital flows could pose challenges for financial stability in the capital recipient countries. ${ }^{1}$

Concerns about the potential risks posed by surges in capital flows have led to reconsideration of the merits of capital control policies (Ostry et al., 2010). Conventional monetary policy is likely to be ineffective in mitigating surges in capital inflows in small open economies, as raising interest rates can have the counterproductive effect of raising the attractiveness of a nation as a destination for foreign investment [e.g. Rey (2013)]. Still, if assets are imperfect substitutes, sterilization may be effectively used as a policy response. By using a combination of capital account restrictions and sterilization of capital flows, a central bank can mitigate the effects of excess foreign capital flows caused by external shocks [e.g. Fernandez-Arias and Montiel (1996), Farhi and Werning (2012) and Unsal (2013)].

However, capital controls and sterilization policies can be costly. Capital controls can be distortionary [e.g. Edwards (1999), Johnson and Mitton (2003)]. Similarly, sterilization policies can have adverse fiscal implications in environments with low prevailing global interest rates. These costs must be incorporated in the pursuit of optimal policy. For example, Chang et al. (2012) show that the large increases in the spread between domestic and foreign interest rates following the crisis raised substantially the cost of sterilization for the People's Bank of China (PBOC). ${ }^{2}$ In the wake of an unexpected decline in foreign interest rates, optimal monetary policy in such an environment includes slowing the pace of sterilization and allowing for increased inflation.

In this paper, we study the effectiveness of capital controls and sterilization policies in a small open economy with incomplete markets and imperfect asset substitutability.

\footnotetext{
${ }^{1}$ Central bankers in advanced economies defended these policies by maintaining that they were appropriate for stimulating their domestic economies, and that ensuring the recovery of the advanced economies was also in the interest of the emerging economies [e.g. Bernanke (2012)].

${ }^{2}$ The PBOC engages in extensive sterilization activity to maintain the country's closed capital account in the face of persistent Chinese current account surpluses.
} 
Our model generalizes the standard small open economy model of Schmitt-Grohé and Uribe (2003) in three dimensions. First, to study the macroeconomic and welfare implications of sterilization policies, we introduce imperfect substitutability between domestic and foreign assets. Specifically, we incorporate adjustment costs for private holdings of foreign and domestic assets. These costs drive a wedge into the standard uncovered interest rate parity (UIP) condition and result in imperfect risk sharing across countries. Second, to study optimal capital control policies, we introduce a time-varying tax on capital inflows. Third, to allow monetary policy to have real effects, we assume that prices are sticky.

We consider optimal Ramsey policy under which the Ramsey planner maximizes the representative household's welfare, taking private sector optimizing decisions as given. In our benchmark model, the planner makes use of not just the conventional monetary policy instruments, but also sterilization activity and capital control policies to maximize welfare. ${ }^{3}$ Sterilization activity takes the form of optimally adjusting the central bank's foreign bond portfolio, while capital control policies are modeled as levying an optimal time-varying tax on foreign earnings on domestic bonds. ${ }^{4}$

Imperfect asset substitutability in the model inhibits international risk sharing and raises the scope for capital account policies to influence macroeconomic stability and welfare. Thus, unlike the standard small open economy model such as that in Galí and Monacelli (2005), even if there are no markup shocks and fiscal subsidies are available to offset steady-state markup distortions, monetary policy in general cannot completely stabilize the welfare-relevant output gap (Corsetti et al., forthcoming). However, this same imperfect asset substitutability allows the central bank to engage in sterilization activity to insulate the economy from external shocks and surges in capital inflows. We therefore explicitly model the central bank's balance-sheet decisions to illustrate the macroeconomic effects of sterilization activity. In addition, we consider the implications of direct capital controls in the form of optimal taxation of foreign earnings on domestic bonds.

Importantly, acting alone, neither of these capital account policies are capable of fully addressing the frictions associated with imperfect asset substitution. Sterilization can influence asset demands, but has fiscal implications that impact on the government budget constraint. Taxes on capital inflows influence foreign demand for domestic

\footnotetext{
${ }^{3}$ The Ramsey policy problem that we consider here is similar to the jointly optimal fiscal and monetary policy problem studied by Schmitt-Grohé and Uribe (2004).

${ }^{4}$ Time-varying capital flow restrictions have been considered in a different context in previous studies [e.g., Jeanne and Korinek (2010) and Korinek (2013)].
} 
assets, but do not directly address the impact of external shocks on domestic household asset demands. Moreover, taxing foreign returns on domestic assets introduces a wedge between domestic and foreign returns, raising distortions. ${ }^{5}$ As such, the joint implementation of both optimal sterilization and capital control policies has potential for improving social welfare, even relative to optimal use of the other stabilizing policy in isolation.

We calibrate our model to examine the effectiveness of the two types of capital account polices - sterilization and capital controls - for macroeconomic stability. We also evaluate welfare outcomes under alternative policy regimes where the Ramsey planner cannot optimally set one or both of the capital account policies.

Our benchmark results suggest that optimal policy makes use of both sterilization and capital controls in the presence of external interest rate shocks or domestic technology shocks. For example, in the wake of a negative foreign interest rate shock in our model, the planner raises simultaneously the government's holdings of foreign reserves and the tax rate on capital inflows. In our calibrated results below, the combination of these polices succeeds in smoothing macroeconomic volatility and increasing welfare.

We then consider three alternative regimes to isolate the impacts of the capital tax and sterilization policies. We first shut off each of these policies in isolation sequentially, and then shut off both of them at once. We shut off sterilization activity by forcing the government foreign reserve holdings to be constant at the steady state level over the course of the business cycle; similarly, when we shut off the capital control policies, we restrict the capital inflow tax to its steady state value throughout the cycle. Comparisons of the welfare outcomes across these regimes, along with our benchmark results, demonstrate the marginal welfare enhancement of introducing each of the policies.

Our welfare results indicate that introducing optimal capital controls policy in an environment with optimal sterilization results in much larger gains than doing so in an environment where the central bank does not sterilize. These results therefore suggest that capital controls and sterilization policies are complementary in addressing external shocks, rather than substitutes. The sensitivity of our conclusions concerning the efficacy of capital controls policies in stabilizing the economy also demonstrates

\footnotetext{
${ }^{5} \mathrm{~A}$ more comprehensive set of capital controls, with different tax schedules to accommodate differences in domestic and foreign asset demand, may mitigate the welfare gains from also engaging in sterilization. However, such a policy would likely be difficult to implement, as it would require different schedules for all of the adjustment margins considered.
} 
the importance of accurate portrayal of the overall policy toolkit when evaluating individual stabilization policies.

The remainder of this paper is divided into four sections. Section II discusses the contributions of this paper relative to literature. Section III introduces the benchmark DSGE model that features imperfect asset substitutability and nominal rigidities. Section IV presents the optimal policy problem and discusses the effectiveness of sterilization and capital control policies for macroeconomic stabilization. There, we also study the welfare implications of alternative policy regimes. Finally, Section V provides some concluding remarks. Some detailed derivations of Ramsey optimal policy problem are presented in the Appendix.

\section{RELATED LiterATURE}

The DSGE model that we examine here provides a coherent theoretical framework for studying optimal monetary policy and for evaluating welfare performances of alternative policy regimes. In the standard DSGE model of a closed economy, monetary policy faces no trade off between stabilizing inflation and stabilizing the output gap (Blanchard and Galí, 2007). This "divine coincidence," which is obtained from a closed economy model, can be carried over to a small open economy with perfect international capital flows and flexible exchange rates (Clarida et al., 2002). Indeed, Obstfeld and Rogoff (2002) show that the gains from international policy coordination may be limited relative to welfare attainable from "self-oriented" monetary policies geared towards national macroeconomic goals. Subsequent literature shows that the divine coincidence breaks down in more general environments, such as one with multiple sources of nominal rigidities. Examples include a model with sticky prices and sticky nominal wages (Erceg et al., 2000), a model with sticky prices in multiple sectors (Mankiw and Reis, 2003; Huang and Liu, 2005), and a model with multiple countries (Benigno, 2004; Liu and Pappa, 2008; Monacelli, 2013). For a survey of the literature on optimal monetary policy in open economies, see, for example, Corsetti et al. (forthcoming).

In our benchmark open-economy model with imperfect international asset substitutability, monetary policy faces additional constraints in stabilizing inflation and output fluctuations. In particular, our analysis follows a growing literature that argues that capital controls may be welfare-enhancing under credit market imperfections. In a recent paper, Jeanne and Korinek (2010) demonstrate that a time-varying Pigouvian tax on borrowing can induce borrowers to internalize the externalities associated 
with international borrowing. Korinek (2013) finds that if such taxes are addressed at neutralizing domestic distortions, outcomes are Pareto efficient and there are no gains from global policy coordination. ${ }^{6}$ Bianchi (2011) also introduces a model with financial frictions and finds that constrained-efficient allocations can be recovered through appropriate state-contingent capital controls, reserve requirements, or margin requirements on borrowing. Farhi and Werning (2012) argue that capital controls can mitigate the effects of excess international capital movements caused by risk premium shocks. Benigno et al. (2014) demonstrate that the desirability of capital controls prior to a crisis may depend on the quality of crisis management tools available. Devereux and Yetman (2014a) demonstrate that capital controls themselves, by limiting capital account openness, can increase the effectiveness of monetary policy responses to external conditions, such as a global liquidity trap.

The efficacy of sterilized intervention has been in question since Backus and Kehoe (1989), who demonstrate that sterilized intervention does not represent an additional instrument for monetary policy. However, our "sterilization" policy here is better understood as analogous to unsterilized intervention in the literature, in the sense that adjustments to the central bank's foreign asset holdings, all else equal, will correspond to changes in monetary policy according to our model's budget constraint for the consolidated government. Of course, these unsterilized interventions are well-understood to have real effects in sticky price models through their influence on monetary conditions [e.g. Olivier Blanchard and Adler (2014)].

General equilibrium modeling of sterilization activity has been relatively scarce. To have real effects of sterilization activity requires a monetary model with imperfect asset substitutability and consequent deviations from uncovered interest rate parity, as in our model. One exception is Kumhof (2010), which demonstrates in a general equilibrium model with money and imperfect asset substitutability that sterilization can act as a second policy instrument. Some others have examined the effects of sterilization policies under a closed capital account. For example, Chang et al. (2012) study sterilization policies for China in a DSGE model with imperfect asset substitutability and a nearly closed capital account. Similarly, Devereux and Yetman (2014b) demonstrate that sterilization policies may enhance welfare under under limited good

\footnotetext{
${ }^{6}$ Capital controls can also be a welfare-enhancing tool as a means of terms of trade manipulation. For a recent example, see Costinot et al. (2011).
} 
market integration. Prasad (2013) demonstrates that even under perfect asset substitutability, sterilized intervention can be welfare enhancing in an environment where the capital account is closed to domestic households.

To our knowledge, however, our paper is the first to examine the relative efficacy of capital controls and sterilization policies for small open economies in a monetary DSGE model in which the mix of money and bond holdings affects real allocations. ${ }^{7}$ Such a model is necessary for proper assessment of the implications of sterilization activity. In the wake of a foreign interest rate shock, increases in the costs of sterilization further constrain the central bank's ability to stabilize domestic price inflation. A monetary model is therefore necessary to evaluate the impact of the sterilization activity. Our results differ from non-monetary open-economy models [e.g. Hevia and Nicolini (2013)] that retain the "divine coincidence" result that price stabilization alone remains optimal in open-economy models with price rigidities.

\section{BENCHMARK MODEL}

We study a small open economy model with a flexible exchange rate regime and a single traded final consumption good. The model generalizes the standard small open economy of Schmitt-Grohé and Uribe (2003) in three dimensions: First, to study optimal sterilization policies, we incorporate portfolio adjustment costs so that domestic and foreign assets are imperfect substitutes and the standard uncovered interest rate parity (UIP) condition does not hold. Second, to study optimal capital control policies, we introduce a time-varying tax on capital inflows. Third, to have real effects of monetary policy, we introduce nominal rigidities.

The country is populated by a continuum of infinitely lived households. The representative household consumes a final good, holds real money balances, and supplies labor hours to firms. The final good is a composite of differentiated products, each of which is produced using labor as the only input. Final goods can be either consumed by domestic households or exported to the foreign country. The law of one price holds for the final goods, so that the real exchange rate is one. All markets are perfectly

\footnotetext{
${ }^{7}$ Unsal (2013) considers a "monetary authority" that follows a standard interest rate rule in a real economy, while Korinek (2013) examines "reserve accumulation," in the sense that a central planner purchases and holds foreign assets on behalf of domestic agents. Monacelli (2013) characterizes optimal monetary policy in an open economy as the constrained-efficient Ramsey allocation under preset prices, but does not consider capital account policies. Chang et al. (2012) look at capital controls and sterilization policy in a DSGE model for the special closed capital account case of China. The capital account in Prasad (2013) is also closed.
} 
competitive, except that the markets for differentiated retail goods are monopolistically competitive. Each firm takes all prices but its own as given and sets a price for its differentiated product. Adjustments in prices are subject to a quadratic cost, as in Rotemberg (1982).

III.1. The households. The representative household has preferences represented by the utility function

$$
U=\mathrm{E} \sum_{t=0}^{\infty} \beta^{t}\left\{\ln c_{t}+\phi_{m} \ln m_{t}-\phi_{l} \frac{l_{t}^{1+\eta}}{1+\eta}\right\},
$$

where $\mathrm{E}$ is an expectation operator, $c_{t}$ denotes consumption of final goods, $m_{t}$ denotes real money balances, and $l_{t}$ denotes labor hours. The parameter $\beta \in(0,1)$ is a subjective discount factor; the non-negative terms $\phi_{m}$ and $\phi_{l}$ are utility weights on real money balances and labor, respectively; and the parameter $\eta>0$ is a curvature parameter that represents the disutility of labor.

The household faces the sequence of budget constraints

$$
\begin{aligned}
c_{t} & +m_{t}+b_{h t}+b_{h t}^{*} \leq w_{t} l_{t}+\frac{m_{t-1}}{\pi_{t}}+R_{t-1} \frac{b_{h, t-1}}{\pi_{t}}+R_{t-1}^{*} b_{h, t-1}^{*} \\
& +d_{t}+T_{t}-\frac{\psi_{1}}{2}\left(b_{h t}-\bar{b}_{h}\right)^{2}-\frac{\psi_{2}}{2}\left(b_{h t}^{*}-\bar{b}_{h}^{*}\right)^{2}
\end{aligned}
$$

where $b_{h t}$ denotes the real value of a domestic bond; $b_{h t}^{*}$ denotes the real value of a foreign-currency bond (in final consumption good units); $R_{t}$ and $R_{t}^{*}$ denote one plus the nominal interest rates on domestic and foreign bonds, respectively; $w_{t}$ denotes the real wage rate; $\pi_{t}$ denotes one plus the domestic inflation rate; $d_{t}$ is the real profit income from the household's ownership shares of firms; and $T_{t}$ is a lump-sum transfer received from the government. The parameters $\psi_{1}$ and $\psi_{2}$ measure the size of the portfolio adjustment costs for domestic and foreign bonds, respectively. The terms $\bar{b}_{h}$ and $\bar{b}_{h}^{*}$ denote the steady-state holdings of domestic and foreign bonds.

In the budget constraint (2), we have assumed that the household takes as given the foreign inflation rate, which is normalized to zero. We have also assumed that the law of one price holds for the final consumption goods, so that the real exchange rate is one. It follows that the nominal exchange rate corresponds to the domestic price level and that changes in the nominal exchange rate corresponds to domestic inflation.

The household chooses $c_{t}, m_{t}, l_{t}, b_{h t}$, and $b_{h t}^{*}$ to maximize the utility function (1) subject to the budget constraints (2). 
The optimal money demand equation is given by

$$
\frac{\phi_{m} c_{t}}{m_{t}}=1-\beta \mathrm{E}_{t} \frac{c_{t}}{c_{t+1}} \frac{1}{\pi_{t+1}}
$$

The optimal labor supply decision equates the real wage rate to the marginal rate of substitution between leisure and consumption. In particular, it is described by the first-order condition

$$
w_{t}=\phi_{l} l_{t}^{\eta} c_{t}
$$

The optimal choice of domestic bond $b_{h t}$ implies the intertemporal Euler equation

$$
1+\psi_{1}\left(b_{h t}-\bar{b}_{h}\right)=\beta \mathrm{E}_{t} \frac{c_{t}}{c_{t+1}} \frac{R_{t}}{\pi_{t+1}} .
$$

Similarly, the optimal choice of foreign bond $b_{h t}^{*}$ implies that

$$
1+\psi_{2}\left(b_{h t}^{*}-\bar{b}_{h}^{*}\right)=\beta \mathrm{E}_{t} \frac{c_{t}}{c_{t+1}} R_{t}^{*} .
$$

Absent portfolio adjustment costs, the standard UIP condition would hold. This can be seen by combining equations (5) and (6) with $\psi_{1}=\psi_{2}=0$ imposed. In the more general case with portfolio adjustment costs, however, domestic and foreign bonds are no longer perfect substitutes and the UIP fails to hold. In this case, equations (5) and (6) represent downward-sloping demand curves for domestic and foreign bonds, respectively. When the relative price of domestic bonds falls, for example, the relative nominal interest rate (adjusted for expected changes in the nominal exchange rate) increases, and the household's optimal holdings of domestic bond increases relative to the steady state level. ${ }^{8}$

The household takes the foreign interest rate $R_{t}^{*}$ as given. We assume that $R_{t}^{*}$ follows the exogenous stochastic process

$$
\ln R_{t}^{*}=\left(1-\rho_{r}\right) \ln R^{*}+\rho_{r} \ln R_{t-1}^{*}+\varepsilon_{r t},
$$

where $\rho_{r}$ denotes the persistence of the shock, $R^{*}$ is the steady-state level of the foreign interest rate, and $\varepsilon_{r t}$ is an innovation to the shock and follows a normal process with a mean of zero and a standard deviation of $\sigma_{r}$.

\footnotetext{
${ }^{8}$ Incorporating portfolio adjustment costs in our model helps pin down equilibrium dynamics of optimal portfolio holdings. More importantly, it implies imperfect substitutability between domestic and foreign assets, and therefore creating a scope for sterilization policy. Our approach is different from Devereux and Sutherland (2011), who propose an approach to obtaining equilibrium portfolio shares in a standard open-economy model without portfolio adjustment costs.
} 
III.2. The firms. There is a continuum of firms, each producing a differentiated product $y_{t}(j)$ using the constant returns technology

$$
y_{t}(j)=Z_{t} l_{t}(j)
$$

where $l_{t}(j)$ denotes labor input for firm $j$ and $Z_{t}$ denotes an aggregate technology shock. The technology shock follows the stationary stochastic process

$$
\ln Z_{t}=\rho_{z} \ln Z_{t-1}+\varepsilon_{z t},
$$

where $\rho_{z}$ is a persistence parameter and $\varepsilon_{z t}$ is an innovation to the technology shock and follows a normal process with a mean of zero and a standard deviation of $\sigma_{z}$. We have normalized the mean level of the technology shock to one.

Firms face a competitive input market and a monopolistically competitive product market. We assume that the final good is a Dixit-Stiglitz aggregator of differentiated products with the aggregation technology

$$
y_{t}=\left[\int_{0}^{1} y_{t}(j)^{\frac{\theta-1}{\theta}} d j\right]^{\frac{\theta}{\theta-1}},
$$

where $\theta>1$ denotes the elasticity of substitution between differentiated products. The optimizing aggregation decisions imply the demand schedule

$$
y_{t}^{d}(j)=\left[\frac{P_{t}(j)}{P_{t}}\right]^{-\theta} y_{t}
$$

where the price level $P_{t}$ is related to the individual prices $P_{t}(j)$ by $P_{t}=\left[\int_{0}^{1} P_{t}(j)^{1-\theta} d j\right]^{\frac{1}{1-\theta}}$.

Firm $j$ takes as given the the real wage rate $w_{t}$, the price level $P_{t}$, and the demand schedule (11), and sets a price $P_{t}(j)$ for its own differentiated product to maximize expected discounted dividend flows. Following Rotemberg (1982), firms are assumed to face a quadratic price adjustment cost

$$
\frac{\psi_{3}}{2}\left(\frac{P_{t}(j)}{\pi P_{t-1}(j)}-1\right)^{2} c_{t}
$$

where $\psi_{3}$ measures the size of the price adjustment costs and $\pi$ is the steady-state inflation rate. We normalize the adjustment cost in aggregate consumption units $c_{t}{ }^{9}$

Firm $j$ solves the problem

$$
\operatorname{Max}_{P_{t}(j)} \quad E_{t} \sum_{k=0}^{\infty} \frac{\beta^{k} \Lambda_{t+k}}{\Lambda_{t}} d_{t+k}(j)
$$

\footnotetext{
${ }^{9}$ The results do not change if we normalize using aggregate output units.
} 
where $d_{t+k}(j)$ denotes the dividend flow from firm $j$ in period $t+k$ and is given by

$$
d_{t+k}(j)=\left(\frac{P_{t+k}(j)}{P_{t+k}}-\frac{w_{t+k}}{Z_{t+k}}\right) y_{t+k}^{d}(j)-\frac{\psi_{3}}{2}\left(\frac{P_{t+k}(j)}{\pi P_{t+k-1}(j)}-1\right)^{2} c_{t+k} .
$$

The optimal price-setting decision implies that, in a symmetric equilibrium with $P_{t}(j)=P_{t}$ for all $j$, we have

$$
\frac{w_{t}}{Z_{t}}=\frac{\theta-1}{\theta}+\frac{\psi_{3}}{\theta} \frac{c_{t}}{y_{t}}\left[\left(\frac{\pi_{t}}{\pi}-1\right) \frac{\pi_{t}}{\pi}-\beta \mathrm{E}_{t}\left(\frac{\pi_{t+1}}{\pi}-1\right) \frac{\pi_{t+1}}{\pi}\right]
$$

Absent price adjustment costs (i.e., when $\psi_{3}=0$ ), the optimal pricing rule would imply that the real marginal cost equals the inverse markup.

III.3. Capital flows and capital control policy. Foreign investors' demand for domestic debt follows the demand schedule

$$
b_{f t}=\psi_{4}\left[\left(1-\tau_{t}\right) \mathrm{E}_{t} \frac{R_{t}}{\pi_{t+1}}-R_{t}^{*}\right]
$$

where $b_{f t}$ denotes the real value (in final consumption good units) of domestic bonds held by foreign investors, $\tau_{t}$ is a time-varying tax rate on the interest earnings for foreign investors through holding domestic bonds, and $\psi_{4}$ is a parameter that captures the sensitivity of foreign demand for domestic bonds to changes in (after-tax) relative returns to domestic and foreign bonds. ${ }^{10}$

When foreign investors' demand for domestic bonds increases, the small open economy experiences a capital inflow. The government may wish to stabilize capital inflows by adjusting the tax rate on interest earnings for foreign investors. We interpret the time-varying tax rate $\tau_{t}$ as an instrument for capital controls. We assume that revenues from taxing foreign capital inflows are rebated to the representative household

${ }^{10}$ The foreign investor's demand schedule (15) can be derived from the foreign consumer's optimizing decisions. In particular, the foreign bond Euler equations (analogous to equations (5) and (6)) imply that

$$
\psi_{1}^{*}\left(b_{f t}^{*}-\bar{b}_{f}^{*}\right)-\psi_{2}^{*}\left(b_{f t}-\bar{b}_{f}\right)=\beta^{*} \mathrm{E}_{t} \frac{c_{t}^{*}}{c_{t+1}^{*}}\left(\frac{R_{t}^{*}}{\pi_{t+1}^{*}}-\frac{R_{t}}{\pi_{t+1}}\left(1-\tau_{t}\right)\right),
$$

where $\psi_{1}^{*}$ and $\psi_{2}^{*}$ are the adjustment-cost parameters for foreign consumers' holdings of foreign bonds $b_{f t}^{*}$ and domestic bonds $b_{f t}$, respectively, and the other starred-variables correspond to the foreign counterparts to the domestic variables. Since the foreign variables are taken as given by the small open economy, we assume - without loss of generality - that all foreign variables (i.e., the starred variables) are constant, except for $R_{t}^{*}$, which follows the stochastic process in equation (7). Further, we normalize the steady-state foreign demand for domestic bonds $\bar{b}_{f}$ to zero. We then obtain equation (15), with $\psi_{4} \equiv \beta^{*} / \psi_{2}^{*}$. 
through lump-sum transfers, so that

$$
T_{t}=\tau_{t-1} \frac{R_{t-1}}{\pi_{t}} b_{f, t-1}
$$

The country also experiences capital outflows since domestic households and the government both hold foreign bonds. We have derived the optimizing decisions for foreign-bond holdings by the household (equation (6)). We now describe how the government adjusts its holdings of foreign bonds (i.e., foreign reserves).

The government faces the flow-of-funds constraints

$$
b_{g t}^{*}-R_{t-1}^{*} b_{g, t-1}^{*} \leq b_{t}-\frac{R_{t-1}}{\pi_{t}} b_{t-1}+m_{t}^{s}-\frac{m_{t-1}^{s}}{\pi_{t}},
$$

where $b_{g t}^{*}$ denotes the real value (in final consumption good units) of the government's holdings of the foreign bond, $b_{t}$ denotes the real value of domestic bond supply, $m_{t}^{s}$ denotes the real value of money supply. The government finances interest payments for matured domestic debt and increases in foreign bond holdings by a combination of new domestic debt issuance, interest payments on matured foreign bonds, and seigniorage revenue from money creation.

The aggregate capital outflow (denoted by $b_{t}^{*}$ ) is therefore given by

$$
b_{t}^{*}=b_{h t}^{*}+b_{g t}^{*} .
$$

The balance of payments then implies that the real value of the current account balance (denoted by $c a_{t}$ ) equals the net foreign capital outflows. Thus, we have

$$
c a_{t}=b_{t}^{*}-b_{t-1}^{*}-\left(b_{f t}-\frac{b_{f, t-1}}{\pi_{t}}\right) .
$$

III.4. Market clearing and equilibrium. In equilibrium, the markets for final goods, labor, money, domestic bonds all clear. Goods market clearing implies that the country's trade balance (or net exports) is given by aggregate output net of domestic consumption and adjustment costs. Denote by $t b_{t}$ the trade balance. We then have

$$
t b_{t}=y_{t}-c_{t}-\frac{\psi_{1}}{2}\left(b_{h t}-\bar{b}_{h}\right)^{2}-\frac{\psi_{2}}{2}\left(b_{h t}^{*}-\bar{b}_{h}^{*}\right)^{2}-\frac{\psi_{3}}{2}\left(\frac{\pi_{t}}{\pi}-1\right)^{2} c_{t} .
$$

The trade balance is related to the current account through

$$
c a_{t}=t b_{t}+\left(R_{t}^{*}-1\right) b_{t-1}^{*}-\left[R_{t-1}\left(1-\tau_{t-1}\right)-1\right] \frac{b_{f, t-1}}{\pi_{t}} .
$$

This relation can be derived by combining the household budget constraint (2) and the government flow-of-funds constraint (17), where the lump-sum transfer is given by equation (16) and the current account balance is given by equation 19. This condition corresponds to the goods market clearing condition. 
The market clearing conditions for labor, money, and domestic bonds are summarized below.

$$
\begin{aligned}
l_{t} & =\int_{0}^{1} l_{t}(j) d j, \\
m_{t}^{s} & =m_{t}, \\
b_{t} & =b_{h t}+b_{f t} .
\end{aligned}
$$

With the labor market clearing condition (22), we obtain the aggregate production function

$$
y_{t}=Z_{t} l_{t} .
$$

Given government policy, an equilibrium in this economy is a sequence of prices $\left\{P_{t}, w_{t}, \pi_{t}, R_{t}\right\}$ and aggregate quantities $\left\{c_{t}, y_{t}, l_{t}, m_{t}, m_{t}^{s}, b_{t}, b_{h t}, b_{f t}, b_{h t}^{*}, b_{g t}^{*}, b_{t}^{*}, t b_{t}, c a_{t}\right\}$, as well as the prices $P_{t}(j)$ and quantities $\left\{y_{t}(j), l_{t}(j)\right\}$ for each firm $j \in[0,1]$, such that (i) taking all prices but its own as given, the price and allocations for each firm solves its profit maximizing problem, (ii) taking all prices as given, the allocations for the households solve the utility maximizing problem, and (iii) markets for the final goods, labor, money balances, and bond holdings all clear.

\section{Optimal POLicy}

Portfolio adjustment costs imply imperfect capital mobility and limited risk sharing. Thus, even if monetary policy can undo the nominal rigidities, the flexible-price equilibrium allocations are still inefficient, leaving room for other policy instruments to improve social welfare. We focus on two such alternative policy instruments: sterilized intervention and capital account restrictions. With sterilized intervention, the government chooses its portfolio composition between foreign reserves, domestic bonds, and the money supply. Under capital account restrictions, the government adjusts the tax rate on capital inflows. In this sense, the planner's problem involves optimal monetary and fiscal policy along the lines, for example, of Schmitt-Grohé and Uribe (2004).

IV.1. The Ramsey problem. To characterize optimal policy, we focus on a Ramsey problem under which the planner sets these policy instruments optimally to maximize the social welfare subject to the private sector's optimizing decisions. We follow Woodford (2003) and focus on optimal commitment policy with a timeless perspective. 
The Ramsey planner has the objective function

$$
\mathrm{E}_{t} \sum_{t=0}^{\infty} \beta^{t}\left[\ln c_{t}-\phi_{l} \frac{l_{t}^{1+\eta}}{1+\eta}\right] .
$$

Note that this objective function corresponds to the value function of the representative household except that the planner does not value real money balances. ${ }^{11}$

The planner maximizes (26) subject to the household's optimizing conditions (3)(6), the firm's optimal pricing decision (14), the capital inflow schedule (15), the government flow-of-funds constraint (17), the market clearing conditions (18)-(24), and the aggregate production function (25). We derive the first-order conditions that characterize the Ramsey problem in the appendix.

Our model is sufficiently complex that it is infeasible to derive an analytical expression for the Ramsey planner's welfare objective based on second-order approximations to the representative household's utility function. Thus, we solve the Ramsey planner's problem numerically based on calibrated parameters. We compute the dynamic responses of macroeconomic variables in the model to a foreign interest rate shock and a technology shock to examine the model's transmission mechanism under Ramsey optimal policy. We also evaluate welfare based on second-order approximations to the Ramsey planner's optimizing decision rules. ${ }^{12}$

IV.2. Parameter calibration. The parameters to be calibrated include $\beta$, the subjective discount factor; $\phi_{m}$ and $\phi_{l}$, the utility weights for real money balances and leisure; $\eta$, the inverse Frisch elasticity of labor supply; $\theta$, the elasticity of substitution between differentiated products; $\psi_{1}$ and $\psi_{2}$, the adjustment cost parameters for domestic and foreign bonds; $\psi_{3}$, the adjustment cost parameter for price setting; $\psi_{4}$, the slope parameter in the foreign investor's demand schedule for domestic bonds; $\rho_{z}$ and $\rho_{r}$, the persistence parameters for the technology shock and foreign interest rate shock processes; and $\sigma_{z}$ and $\sigma_{r}$, the standard deviations of the two shocks. Table 1 displays the calibrated values of these parameters.

Since we have a quarterly model, the subjective discount factor $\beta$ is set to 0.99 , so that the steady-state real interest rate is 4 percent. Based on the money demand

\footnotetext{
${ }^{11}$ See also Woodford (2003).

${ }^{12}$ Evaluating welfare requires second-order approximations because the model's risky steady state is in general different from the deterministic steady state (Kim et al., 2008; Coeurdacier et al., 2011). Our approach to evaluating welfare based on second-order approximations is similar to the approach used by Schmitt-Grohé and Uribe (2004), which takes into account of potential effects of the risky steady state.
} 
regression by Chari et al. (2000), we set $\Phi_{m}=0.06$. We set $\eta=2$, so that the Frisch elasticity of labor supply is 0.5 , which is consistent with empirical studies Keane and Rogerson (2011). We calibrate $\phi_{l}$ so that the steady-state labor hours are about 30 percent of the time endowment The elasticity of substitution between differentiated products is set to $\theta=10$, implying a steady-state markup of about 11 percent, which lies in the range estimated by Basu and Fernald (1997). We set the price adjustment cost parameter to $\psi_{3}=60$, which is consistent with an average duration of price contracts of about three quarters, in line with empirical evidence on price rigidities (Nakamura and Steinsson, 2008). ${ }^{13}$ We have less guidance for calibrating the portfolio adjustment cost parameters. We set $\phi_{j}=0.01$ as a baseline $(j \in\{1,2,4\})$ and we examine the sensitivity of our results for different values of these adjustment cost parameters. For the shock parameters, we set the persistence to $\rho_{z}=0.9$ and $\rho_{r}=0.9$ and the standard deviations to $\sigma_{z}=0.005$ and $\sigma_{r}=0.001 .^{14}$

In all our numerical experiments below, we focus on a steady state equilibrium with zero inflation (i.e., $\bar{\pi}=1$ ), no capital flow taxes $(\bar{\tau}=0)$, no government holdings of foreign reserves $\left(\bar{b}_{g}^{*}=0\right)$, and with a ratio of trade balance to aggregate output of 2 percent.

IV.3. Optimal policy outcomes. We now discuss the optimal policy outcomes. In the benchmark case, we assume that the Ramsey planner optimally sets both sterilized interventions (by varying the amount of foreign reserves) and capital account restrictions (by varying the tax rate on capital inflows) to maximize the social welfare, taking as given the private-sector's optimizing decisions. We then consider three alternative regimes, each being a special case of the benchmark policy. In the first regime, the planner optimally sets capital control policies but not sterilization policies. Thus, while the tax rate on capital inflows is adjusted optimally, the amount of foreign reserves is held fixed at the steady-state value (i.e., $b_{g t}^{*}=\bar{b}_{g}^{*}=0$ ). In the second regime, the capital-inflow tax rate is held at the steady-state value (i.e., $\tau_{t}=\bar{\tau}=0$ ),

\footnotetext{
${ }^{13}$ The slope of the Phillips curve in our model is given by $\kappa \equiv \frac{\theta-1}{\psi_{3}} \frac{C}{Y}$, where the steady-state ratio of consumption to gross output is 0.98 (so that the steady-state trade balance to output ratio is 2 percent, as in Mendoza (1991)). The values of $\theta=10$ and $\psi_{3}=60$ imply that $\kappa=0.153$. In an economy with Calvo (1983) price contracts, the slope of the Phillips curve is given by $\frac{\left(1-\beta \alpha_{p}\right)\left(1-\alpha_{p}\right)}{\alpha_{p}}$, where $\alpha_{p}$ is the probability that a firm cannot reoptimize prices. A slope of 0.153 for the Phillips curve in the Calvo model implies that $\alpha_{p}=0.68$ (taking $\beta=0.99$ as given), which corresponds to an average price contract duration of about 3 quarters. The study by Nakamura and Steinsson (2008) shows that the median price contract duration is between 8 and 12 months.

${ }^{14}$ The qualitative results do not change for a reasonable range of these shock parameters.
} 
while the foreign reserve position is optimally adjusted. In the third regime, both the capital-inflow taxes and the foreign reserves are held at their steady-state values and therefore neither capital controls nor sterilization is optimally set by the planner. In the third regime, the only instrument for the planner is domestic monetary policy (by choosing either the nominal interest rate or the inflation rate).

IV.3.1. Impulse responses. Figure 1 shows the impulse responses of macroeconomic variables to an unexpected decline in the foreign interest rate in the benchmark case. The shock leads to a reduction in capital outflows and an increase in capital inflows. The balance of payments implies that the current account goes into deficit. The decline in foreign demand reduces aggregate output and inflation. Since the real exchange rate is constant under the law of one price, the decline in inflation corresponds to a nominal exchange rate appreciation.

Optimal Ramsey policy calls for an easing of domestic monetary policy by reducing the domestic nominal interest rate. Such policy easing helps alleviate the declines in output and inflation. Optimal policy also calls for stabilization of the impact of capital flows through increased holdings of foreign securities and tightened capital controls. To implement the latter, the government raises the tax rate on the returns for foreign investors. The combination of these capital account policies smoothes fluctuations in capital flows (e.g., the response of $b_{f t}$ is close to zero). Furthermore, the increase in foreign reserves, combined with the decline in domestic bond supply, implies a large increase in money supply and thus a highly expansionary monetary policy. As a consequence, domestic consumption rises despite the fall in aggregate output, implying a large decline in the trade balance (not shown). ${ }^{15}$

Figure 2 shows the impulse responses to an unexpected negative technology shock in the benchmark case. Similar to that in the standard New Keynesian model, a decline in aggregate productivity reduces output and raises inflation. As inflation rises, the planner tightens monetary policy by raising the nominal interest rate. However, the increase in the nominal interest rate does not sufficiently compensate for the increase in inflation, leading to a decline in the real interest rate. With a lower real return, the demand for domestic bonds falls, resulting in a reduction in capital inflows and

\footnotetext{
${ }^{15}$ To keep our analysis tractable, our model has neither capital nor non-tradable goods. In a more general model with investment, foreign interest rate declines may trigger capital inflow surges and could lead to investment booms, potentially raising output and inflation. Nonetheless, we would expect the sterilization and capital control policies that we consider here to be similarly useful for stabilization in these environments.
} 
raising the scope for stabilization through sterilized intervention or capital control policy adjustments. The planner therefore lowers the tax rate on foreign earnings and reduces its holdings of foreign reserves. Again, the planner is able to effectively insulate capital inflows from the productivity shock (the impulse responses of $b_{f t}$ is close to zero). At the same time, since the foreign interest rate does not change, the household demand for foreign bonds does not change either. ${ }^{16}$ Thus, the overall capital outflow declines. The tightening of policy, coupled with the decline in aggregate productivity, leads to a persistent fall in consumption.

Figure 3 compares the impulse responses to a negative foreign interest rate shock in the benchmark case (the blue solid lines) with those under two alternative policy regimes - one with no capital controls $\left(\tau_{t}=0\right.$, the red dashed lines) and the other with no sterilized interventions $\left(b_{g t}^{*}=0\right.$, the green dashed and dotted lines). With no time-varying capital controls, the planner sets the sterilization policy optimally. The macroeconomic responses to the foreign interest rate shock are virtually identical to those in the benchmark case where the planner optimally sets both capital controls and sterilization policies, except that the responses of capital inflows are different. When the capital inflow taxes are restricted to be zero, resisting the inflow surge becomes more costly, so the planner no longer chooses to fully stabilize the inflows triggered by the foreign interest rate decline. Unlike the benchmark case, capital inflows display a persistent increase.

If, on the other hand, the planner cannot choose sterilization policy but can adjust capital inflow taxes, then the capital inflows move in the opposite direction. In this case, without the ability to sterilize capital flows, the planner raises the capital account tax rate more aggressively than in the benchmark case, leading to a drop in capital inflows. This leads to much sharper declines in output, inflation, and capital outflows. As in the benchmark case, the central bank accommodates the recessionary effects of the shock by lowering the nominal interest rate. However, since the foreign reserve holdings cannot be adjusted, the planner cuts the domestic bond supply sharply, implying an increase in the money supply. The expansionary monetary policy raises domestic consumption and, with the fall in output, lowers the trade balance.

Figure 4 compares the impulse responses to a negative technology shock across the three different policy regimes: the benchmark (the blue solid lines), the regime with no capital controls (the red dashed lines), and the one with no sterilized interventions

\footnotetext{
${ }^{16}$ This can be seen from a first-order approximation of the Euler equation 6 for the household's foreign bond holdings.
} 
(the green dashed and dotted lines). The differences of the impulse responses across policy regimes are broadly similar to the case with a foreign interest rate shock. In particular, the macroeconomic responses under the regime with no capital controls are virtually identical to those in the benchmark regime, except that the responses of capital inflows are different. In the benchmark regime, the planner is able to smooth fluctuations in capital inflows by cutting the tax rate. When the taxes are restricted to be zero, however, a negative technology shock leads to a decline in capital inflows because the domestic real interest rate falls, as the inflation rate rises more than the nominal interest rate. In the case in which sterilized interventions are not pursued, the planner reduces capital inflow taxes more aggressively than in the benchmark case. As a result, the shock leads to an increase in capital inflows despite the decline in domestic real interest rates. Inflation also rises more than in the benchmark case, forcing the planner to tighten even more by raising the nominal interest rate. The policy tightening along with the negative technology shock result in more persistent declines in consumption than in the benchmark case.

IV.3.2. Macroeconomic stability and welfare. Table 2 shows the macroeconomic stability and welfare outcomes under the benchmark policy regime along with the three alternative regimes. These results are obtained with the economy exposed to both technology shocks and foreign interest rate shocks. We evaluate welfare losses in terms of consumption equivalence for the three alternative regimes, i.e., how much additional consumption would be required to yield welfare comparable to the benchmark case where both sterilization and capital control policies are optimally set by the Ramsey planner. Our model is sufficiently stylized that we would not stress the particular quantitative results. Instead, we focus on the qualitative results, which prove to be intuitive and helpful for understanding the implications of sterilization and capital control policies in our model framework.

The results for macroeconomic stability are consistent with the intuition from our analysis of the impulse responses. In particular, the results suggest that optimal sterilization policy is quite effective for stabilizing macroeconomic fluctuations driven by the two types of shocks, while optimal capital control policy less so. To see this, we first compare the outcomes under the benchmark policy regime with both optimal sterilization and capital inflow taxes (the first column, under the title "Benchmark") with those in the alternative regime where the planner is able to optimize over sterilization policies but cannot vary the capital inflow tax rate (the second column, under the title "No capital controls"). The volatilities of aggregate output, inflation, and 
the nominal interest rate are virtually identical between these two regimes, although both capital inflows, outflows, and foreign reserves are somewhat more volatile in the alternative regime than in the benchmark regime. These macroeconomic stability outcomes are consistent with the impulse responses to the external interest rate shock shown in Figure 3. However, the impulse responses also show that the sterilizationonly regime (i.e., the one without capital controls) fails to stem the capital inflows triggered by the decline in the foreign interest rate.

Despite the apparent similarities in macroeconomic stability outcomes, shutting off capital controls leads to significant welfare losses relative to the benchmark regime. The table shows that the welfare loss incurred by moving from the benchmark regime to the sterilization-only regime (without capital controls) is equivalent to about 1.23 percent of steady-state consumption. ${ }^{17}$ Therefore, allowing the planner to optimally set both sterilization and capital control policies would lead to superior welfare outcomes.

Comparing the first and the third column in the table reveals that shutting off sterilization leads to substantially greater macroeconomic volatilities. Without the ability to vary foreign reserve holdings, the planner has limited capacity to pursue domestic monetary policy for achieving macroeconomic stability. This finding is consistent with the impulse responses shown, for example, in Figure 3 in the case with an unexpected decline in the foreign interest rate. As we have discussed in Section IV.3.1, the planner accommodates the recessionary effects of the shock by easing domestic monetary policy. In the benchmark regime, the ability to increase the amount of foreign reserves expands the planner capacity for pursing monetary policy easing because reserve acquisitions need to be financed by seigniorage through increases in money supply. In the alternative regime where the planner cannot vary the holdings of foreign reserves, the capacity for monetary policy easing would be more restrained. Thus, the same shock would lead to sharper declines in aggregate output and inflation in the regime with no sterilization, despite that the planner can adjust capital inflow taxes to stability capital flow fluctuations. In addition, moving from the benchmark policy regime to the one with no sterilization (and capital controls only) results in greater welfare

\footnotetext{
${ }^{17}$ Our simulation results suggest that this welfare loss mainly stems from a modest reductions in the stochastic mean of consumption under the constrained regime. Because of imperfect risk-sharing, our steady state outcome is also distorted. This leaves first-order terms such as the stochastic mean of consumption relevant for welfare. This drives the distinction in welfare outcomes between the first and second regimes despite the apparently similar second-order macroeconomic stability outcomes.
} 
losses than moving to the regime with no capital controls (and sterilization only), as shown in the table.

When both sterilization and capital controls are taken away from the planner's policy toolkit, the only policy instrument available for the planner would be domestic monetary policy (e.g., by using the nominal interest rate as an instrument). Comparing the first and the last columns in Table 2 reveals that such an alternative regime would result in greater macroeconomic volatilities and significant welfare losses relative to the benchmark. Furthermore, the macroeconomic implications of this most restrictive capital account regime are similar to those in the regime with no sterilization policy (with capital controls only). This last finding confirms that allowing the planner to purse optimal sterilization policies helps achieve superior macroeconomic stability and welfare outcomes, with or without optimal capital control policies.

Finally, it is interesting to compare the welfare outcomes seen from shutting off the capital controls policy from our benchmark case (i.e. moving from the first to the second column) and that obtained from allowing capital control implementation under an environment with both policies shut off (i.e. moving from column four to column three). We observe almost no welfare gain from allowing capital controls in an environment that does not allow for sterilization policy. In contrast, we observe a non-trivial decline in welfare when shutting off capital controls policy alone relative to the regime where both policies are allowed. The observed gains to the use of capital controls in our model are therefore sensitive to the presence or absence of sterilization policy. When the central bank can use sterilization, the gains from optimal capital controls policy are shown to be non-trivial. This implies that the two types of stabilization policies are complementary. However, a model which shuts off this channel might erroneously reach the conclusion that the stability gains from capital controls are modest. It is therefore important to accurately depict the available set of policy options when assessing the stability contributions of any individual policy. ${ }^{18}$

\section{Conclusion}

This paper examines the effectiveness of sterilization and capital control policies in stabilizing macroeconomic fluctuations in a small open economy. We compare welfare outcomes when these policies are used in concert and in isolation. Imperfect asset

\footnotetext{
${ }^{18}$ Since our model is stylized and we focus on specific shocks and specific types of asset market frictions, the magnitude of relative welfare losses can be sensitive to the inclusion of other shocks and frictions in the model. We leave for future research to investigate the welfare implications of capital account policies in a model with more realistic frictions and a broader set of shocks.
} 
substitutability in our model leads to distortions on capital flows. This distortion creates a role for sterilization and capital control policies to improve welfare in the face of external shocks beyond the use of conventional monetary policies alone.

We find that these capital account policies play an important role in isolating the small open economy from external and domestic shocks. We also find that the welfare improvement associated with the introduction of either of these policies is much greater when the other policy is also being implemented. Thus, our results suggest that sterilization and capital controls serve as complements, rather than substitutes. Our findings demonstrate the importance of correctly specifying the overall policy toolkit when evaluating the contributions of individual stabilization policies. 
Appendix A. Derivations of the Ramsey optimal policy problem

In this appendix, we derive the Ramsey planner's optimizing decisions. The planner maximizes the welfare objective

$$
\mathrm{E}_{t} \sum_{t=0}^{\infty} \beta^{t}\left[\ln c_{t}-\phi_{l} \frac{l_{t}^{1+\eta}}{1+\eta}\right],
$$

taking as given the private sector's optimizing decisions summarized below.

$$
\begin{aligned}
\frac{\phi_{m} c_{t}}{m_{t}} & =1-\beta \mathrm{E}_{t} \frac{c_{t}}{c_{t+1}} \frac{1}{\pi_{t+1}}, \\
w_{t} & =\phi_{l} l_{t}^{\eta} c_{t}, \\
1 & +\psi_{1}\left(b_{h t}-\bar{b}_{h}\right)=\beta \mathrm{E}_{t} \frac{c_{t}}{c_{t+1}} \frac{R_{t}}{\pi_{t+1}} \\
1 & +\psi_{2}\left(b_{h t}^{*}-\bar{b}_{h}^{*}\right)=\beta \mathrm{E}_{t} \frac{c_{t}}{c_{t+1}} R_{t}^{*} \\
\frac{w_{t}}{Z_{t}} & =\frac{\theta-1}{\theta}+\frac{\psi_{3}}{\theta} \frac{c_{t}}{y_{t}}\left[\left(\frac{\pi_{t}}{\pi}-1\right) \frac{\pi_{t}}{\pi}-\beta \mathrm{E}_{t}\left(\frac{\pi_{t+1}}{\pi}-1\right) \frac{\pi_{t+1}}{\pi}\right], \\
b_{f t} & =\psi_{4}\left[\left(1-\tau_{t}\right) \mathrm{E}_{t} \frac{R_{t}}{\pi_{t+1}}-R_{t}^{*}\right] \\
b_{g t}^{*} & -R_{t-1}^{*} b_{g, t-1}^{*}=b_{t}-\frac{R_{t-1}}{\pi_{t}} b_{t-1}+m_{t}-\frac{m_{t-1}}{\pi_{t}}, \\
b_{t} & =b_{h t}+b_{f t}, \\
b_{t}^{*} & =b_{h t}^{*}+b_{g t}^{*}, \\
y_{t} & =Z_{t} l_{t} . \\
c a_{t} & =b_{t}^{*}-b_{t-1}^{*}-\left(b_{f t}-\frac{b_{f, t-1}}{\pi_{t}}\right) \\
t b_{t} & =y_{t}-c_{t}-\frac{\psi_{1}}{2}\left(b_{h t}-\bar{b}_{h}\right)^{2}-\frac{\psi_{2}}{2}\left(b_{h t}^{*}-\bar{b}_{h}^{*}\right)^{2}-\frac{\psi_{3}}{2}\left(\frac{\pi_{t}}{\pi}-1\right)^{2} c_{t}, \\
c a_{t} & =t b_{t}+\left(R_{t}^{*}-1\right) b_{t-1}^{*}-\left[R_{t-1}\left(1-\tau_{t-1}\right)-1\right] \frac{b_{f, t-1}}{\pi_{t}},
\end{aligned}
$$

To keep the Ramsey problem tractable, we further reduce the set of private optimizing conditions by substituting out the six variables $w_{t}, b_{h t}, b_{h t}^{*}, l_{t}, c a_{t}$, and $t b_{t}$ using equations (A3) and (A9)-(A13). The private optimizing conditions can then be reduced to 7 equations. 
The Lagrangian for the Ramsey planner's optimal policy problem is given by

$$
\begin{aligned}
\mathcal{L} & =\mathrm{E}_{t} \sum_{t=0}^{\infty} \beta^{t}\left\{\ln c_{t}-\phi_{l} \frac{l_{t}^{1+\eta}}{1+\eta}\right. \\
& \lambda_{1 t}\left\{1-\beta \frac{c_{t}}{c_{t+1}} \frac{1}{\pi_{t+1}}-\frac{\phi_{m} c_{t}}{m_{t}}\right\} \\
& \lambda_{2 t}\left\{\beta \frac{c_{t}}{c_{t+1}} \frac{R_{t}}{\pi_{t+1}}-1-\psi_{1}\left(b_{t}-b_{f t}-\bar{b}_{h}\right)\right\} \\
& \lambda_{3 t}\left\{\beta \frac{c_{t}}{c_{t+1}} R_{t}^{*}-1-\psi_{2}\left(b_{t}^{*}-b_{g t}^{*}-\bar{b}_{h}^{*}\right)\right\} \\
& \lambda_{4 t}\left\{\frac{\theta-1}{\theta}+\frac{\psi_{3}}{\theta} \frac{c_{t}}{y_{t}}\left[\left(\frac{\pi_{t}}{\pi}-1\right) \frac{\pi_{t}}{\pi}-\beta\left(\frac{\pi_{t+1}}{\pi}-1\right) \frac{\pi_{t+1}}{\pi}\right]-\phi_{l} \frac{y_{t}^{\eta} c_{t}}{Z_{t}^{1+\eta}},\right\} \\
& \lambda_{5 t}\left\{b_{t}-\frac{R_{t-1}}{\pi_{t}} b_{t-1}+m_{t}-\frac{m_{t-1}}{\pi_{t}}-b_{g t}^{*}+R_{t-1}^{*} b_{g, t-1}^{*}\right\} \\
& \lambda_{6 t}\left\{\psi_{4}\left[\left(1-\tau_{t}\right) \frac{R_{t}}{\pi_{t+1}}-R_{t}^{*}\right]-b_{f t}\right\} \\
\lambda_{7 t} & \left\{y_{t}-c_{t}-\frac{\psi_{1}}{2}\left(b_{t}-b_{f t}-\bar{b}_{h}\right)^{2}-\frac{\psi_{2}}{2}\left(b_{t}^{*}-b_{g t}^{*}-\bar{b}_{h}^{*}\right)^{2}-\frac{\psi_{3}}{2}\left(\frac{\pi_{t}}{\pi}-1\right)^{2} c_{t}+\right. \\
\left.R_{t-1}^{*} b_{t-1}^{*}-\frac{R_{t-1}}{\pi_{t}}\left(1-\tau_{t-1}\right) b_{f, t-1}-b_{t}^{*}+b_{f t}\right\} & (\mathrm{A}
\end{aligned}
$$

The planner solves the optimal policy problem by choosing the 10 endogenous variables summarized in the vector

$$
X_{t} \equiv\left[c_{t}, m_{t}, \pi_{t}, b_{t}, b_{f t}, R_{t}, b_{t}^{*}, b_{g t}^{*}, y_{t}, \tau_{t}\right]
$$

along with the 7 Lagrangian multipliers $\lambda j t$ for $j \in\{1,2, \ldots, 7\}$. The first-order conditions are summarized below.

$$
\begin{aligned}
0= & 1-\lambda_{1 t}\left[\frac{\phi_{m} c_{t}}{m_{t}}+\mathrm{E}_{t} \beta \frac{c_{t}}{c_{t+1}} \frac{1}{\pi_{t+1}}\right]+\mathrm{E}_{t} \lambda_{2 t} \beta \frac{c_{t}}{c_{t+1}} \frac{R_{t}}{\pi_{t+1}}+\mathrm{E}_{t} \lambda_{3 t} \beta \frac{c_{t}}{c_{t+1}} R_{t}^{*}-\lambda_{4 t} \phi_{l} \frac{y_{t}^{\eta} c_{t}}{Z_{t}^{1+\eta}} \\
& +\lambda_{4 t} \frac{\psi_{3}}{\theta} \frac{c_{t}}{y_{t}}\left[\left(\frac{\pi_{t}}{\pi}-1\right) \frac{\pi_{t}}{\pi}-\beta \mathrm{E}_{t}\left(\frac{\pi_{t+1}}{\pi}-1\right) \frac{\pi_{t+1}}{\pi}\right]-\lambda_{7 t} \frac{\psi_{3}}{2}\left(\frac{\pi_{t}}{\pi}-1\right)^{2}+ \\
& \lambda_{1, t-1} \frac{c_{t-1}}{c_{t} \pi_{t}}-\lambda_{2, t-1} \frac{c_{t-1}}{c_{t}} \frac{R_{t-1}}{\pi_{t}}-\lambda_{3, t-1} \frac{c_{t-1}}{c_{t}} R_{t-1}^{*} \\
0= & \lambda_{1 t} \frac{\phi_{m} c_{t}}{m_{t}^{2}}+\lambda_{5 t}-\beta \mathrm{E}_{t} \frac{\lambda_{5, t+1}}{\pi_{t+1}} \\
0= & \lambda_{1, t-1} \frac{c_{t-1}}{c_{t} \pi_{t}}-\lambda_{2, t-1} \frac{c_{t-1}}{c_{t}} \frac{R_{t-1}}{\pi_{t}}+\lambda_{4 t} \frac{\psi_{3}}{\theta} \frac{c_{t}}{y_{t}}\left(2 \pi_{t}-1\right) \pi_{t}-
\end{aligned}
$$




$$
\begin{aligned}
& \lambda_{4, t-1} \frac{\psi_{3}}{\theta} \frac{c_{t-1}}{y_{t-1}}\left(2 \pi_{t-1}-1\right) \pi_{t}+\lambda_{5 t}\left[\frac{R_{t-1}}{\pi_{t}} b_{t-1}+\frac{m_{t-1}}{\pi_{t}}\right]- \\
& \lambda_{6, t-1} \frac{\psi_{4}}{\beta}\left(1-\tau_{t-1}\right) \frac{R_{t-1}}{\pi_{t}}-\lambda_{7 t} \psi_{3}\left(\frac{\pi_{t}}{\pi}-1\right) \pi_{t} c_{t}+\lambda_{7 t} \frac{R_{t-1}}{\pi_{t}}\left(1-\tau_{t-1}\right) b_{f, t-1}, \\
0= & -\lambda_{2 t} \psi_{1}+\lambda_{5 t}-\mathrm{E}_{t} \beta \lambda_{5, t+1} \frac{R_{t}}{\pi_{t+1}}-\lambda_{7 t} \psi_{1}\left(b_{t}-b_{f t}-\bar{b}_{h}\right), \\
0= & \lambda_{2 t} \psi_{1}-\lambda_{6 t}+\lambda_{7 t}\left[1+\psi_{1}\left(b_{t}-b_{f t}-\bar{b}_{h}\right)\right]-\mathrm{E}_{t} \beta \lambda_{7, t+1} \frac{R_{t}}{\pi_{t+1}}\left(1-\tau_{t}\right), \\
0= & \mathrm{E}_{t} \lambda_{2 t} \beta \frac{c_{t}}{c_{t+1}} \frac{1}{\pi_{t+1}}-\mathrm{E}_{t} \beta \lambda_{5, t+1} \frac{b_{t}}{\pi_{t+1}}+\lambda_{6 t} \psi_{4}\left(1-\tau_{t}\right) \mathrm{E}_{t} \frac{1}{\pi_{t+1}}- \\
& \mathrm{E}_{t} \beta \lambda_{7, t+1}\left(1-\tau_{t}\right) b_{f t} \frac{1}{\pi_{t+1}}, \\
0 & -\lambda_{3 t} \psi_{2}-\lambda_{7 t}\left[1+\psi_{2}\left(b_{t}^{*}-b_{g t}^{*}-\bar{b}_{h}^{*}\right)\right]+\mathrm{E}_{t} \beta \lambda_{7, t+1} R_{t}^{*}, \\
0 & \lambda_{3 t} \psi_{2}-\lambda_{5 t}+\mathrm{E}_{t} \beta \lambda_{5, t+1} R_{t}^{*}+\lambda_{7 t} \psi_{2}\left(b_{t}^{*}-b_{g t}^{*}-\bar{b}_{h}^{*}\right), \\
0= & -\phi_{l} \frac{y_{t}^{\eta}}{Z_{t}^{1+\eta}}-\lambda_{4 t} \eta \phi_{l} \frac{y_{t}^{\eta-1} c_{t}}{Z_{t}^{1+\eta}}- \\
& \lambda_{4 t} \frac{\psi_{3}}{\theta} \frac{c_{t}}{y_{t}^{2}}\left[\left(\frac{\pi_{t}}{\pi}-1\right) \frac{\pi_{t}}{\pi}-\beta\left(\frac{\pi_{t+1}}{\pi}-1\right) \frac{\pi_{t+1}}{\pi}\right]+\lambda_{7 t}, \\
0= & -\lambda_{6 t} \psi_{4} \mathrm{E}_{t} \frac{R_{t}}{\pi_{t+1}}+\mathrm{E}_{t} \beta b_{f t} \lambda_{7, t+1} \frac{R_{t}}{\pi_{t+1}} .
\end{aligned}
$$

The Ramsey optimal policy solution corresponds to the solution to the 17 equations (A2), (A4)-(A8), (A14), and (A16)-(A25) for the 17 variables including the 10 variables in the vector $X_{t}$ and the 7 Lagrangian multipliers for the Ramsey problem.

We solve the Ramsey problem with calibrated parameters. To evaluate welfare under the Ramsey optimal policy, we solve the Ramsey problem by taking secondorder approximations of all optimizing decisions around the Ramsey steady state. This approach takes into account the effects of shocks on the stochastic means of the endogenous variables, which are important for welfare calculations (Schmitt-Grohé and Uribe, 2004; Kim et al., 2008) 


\section{REFERENCES}

Backus, D. K. And P. J. Kehoe (1989): "On the Denomination of Government Debt: A Critique of the Portfolio Balance Approach," 23, 359-376.

Basu, S. And J. G. Fernald (1997): "Returns to Scale in U.S. Production: Estimates and Implications," 105, 249-283.

Benigno, G., H. Chen, C. Otrok, A. Rebucci, And E. R. Young (2014): "Optimal Capital Controls and Real Exchange Rate Policies: A Pecuniary Externality Perspective," CEPR Discussion Paper No. 9936.

Benigno, P. (2004): "Optimal monetary policy in a currency area," Journal of International Economics, 63, 293-320.

Bernanke, B. S. (2012): "U.S. Monetary Policy and International Implications," Speech at the "Challenges of the Global Financial System: Risks and Governance under Evolving Globalization," A High-Level Seminar sponsored by Bank of JapanInternational Monetary Fund, Tokyo, Japan.

BiAnCHI, J. (2011): "Overborrowing and Systemic Externalities in the Business Cycle," American Economic Review, 101, 3400-3426.

Blanchard, O. J. And J. Galí (2007): "Real Wage Rigidities and the New Keynesian Model," Journal of Money, Credit, and Banking, 39, 35-65.

Calvo, G. A. (1983): "Staggered Prices in a Utility-Maximizing Framework," 12, 383-398.

Chang, C., Z. Liu, and M. M. Spiegel (2012): "Capital Controls and Optimal Chinese Monetary Policy," Federal Reserve Bank of San Francisco Working Paper 2012-13.

Chari, V., P. J. Kehoe, and E. R. McGrattan (2000): "Sticky Price Models of The Business Cycle: Can The Contract Multiplier Solve The Persistence Problem?" Econometrica, 68, 1151-1180.

Clarida, R., J. Galí, and M. Gertler (2002): "Optimal Monetary Policy in Open versus Closed Economies: An Integrated Approach," American Economic Review, 91, 248-252.

Coeurdacier, N., H. Rey, And P. Winant (2011): "The Risky Steady State," American Economic Review: Papers \& Proceedings, 101, 398-401.

Corsetti, G., L. Dedola, And S. Leduc (forthcoming): "Optimal Monetary Policy in Open Economies," in Handbook of Monetary Economics, ed. by M. Woodford and B. Friedman, Elsevier. 
Costinot, A., G. Lorenzoni, And I. Werning (2011): "A Theory of Capital Controls as Dynamic Terms of Trade Manipulation," NBER Working Paper 17680. Devereux, M. B. And A. Sutherland (2011): "Country Portfolios In Open Economy MacroâĂ?Models," Journal of the European Economic Association, 9, 337-369.

Devereux, M. B. And J. Yetman (2014a): "Capital Controls, Global Liquidity Traps, and the International Policy Trilemma," Journal of Scandinavian Economics, 116, 218-313.

(2014b): "Globalisation, pass-through and the optimal policy response to exchange rates," Journal of International Money and Finance, 49, 104-128.

Edwards, S. (1999): "How Effective Are Capital Controls?" Journal of Economic Perspectives, 13, 65-84.

Erceg, C. J., D. W. Henderson, And A. T. Levin (2000): "Optimal Monetary Policy with Staggered Wage and Price Contracts," Journal of Monetary Economics, 46, 218-313.

FArhi, E. And I. Werning (2012): "Dealing with the Trilemma: Optimal Capital Controls with Fixed Exchange Rates," NBER Working Paper 18199.

Fernandez-Arias, E. And P. J. Montiel (1996): "The Surge in Capital Inflows to Developing Countries: An Analytical Overview," The World Bank Economic Review, 10, 51-77.

Galí, J. And T. Monacelli (2005): "Monetary Policy and Exchange Rate Volatility in a Small Open Economy," The Review of Economic Studies, 72, pp. 707-734.

Ghosh, A. R., M. S. Qureshi, J. I. Kim, And J. Zalduendo (2014): "Surges," Journal of International Economics, 92, 266-285.

Hevia, C. And J. P. Nicolini (2013): "Optimal Devaluations," IMF Economic Review, 61, 22-51.

Huang, K. X. And Z. LiU (2005): "Inflation Targeting: What Inflation Rate to Target?" Journal of Monetary Economics, 52, 1435-1462.

Jeanne, O. And A. KorineK (2010): "Managing Credit Booms and Busts: A Pigouvian Taxation Approach," NBER Working Paper No. 16377.

Johnson, S. And T. Mitton (2003): "Cronyism and Capital Controls," Journal of Financial Economics, 67, 351-382.

Keane, M. P. and R. Rogerson (2011): "Reconciling Micro and Macro Labor Supply Elasticities: A Structural Perspective," NBER Working Paper 17430.

Kim, J., S. Kim, E. Schaumburg, and C. A. Sims (2008): "Calculating and Using Second-Order Accurate Solutions of Discrete Time Dynamic Equilibrium Models," 
Journal of Economic Dynamics and Control, 32, 3397-3414.

Korinek, A. (2013): "Capital Controls and Currency Wars," Manuscript, University of Maryland.

Kumhof, M. (2010): "On the Theory of Sterilized Foreign Exchange Intervention," Journal of Economic Dynamics and Control, 34, 1403-1420.

LiU, Z. AND E. PAPPA (2008): "Gains from International Monetary Policy Coordination: Does It Pay to Be Different?" Journal of Economic Dynamics and Control, $32,2085-2117$.

Mankiw, N. G. AND R. ReIs (2003): "What Measure of Inflation Should a Central Bank Target?" Journal of European Economic Association, 1, 1058-1086.

MendozA, E. (1991): "Real business cycles in a small-open economy," American Economic Review, 81, 797-818.

Monacelli, T. (2013): "Is Monetary Policy in an Open Economy Fundamentally Different?" IMF Economic Review, 61, 6-21.

Nakamura, E. And J. Steinsson (2008): "Five Facts About Prices: A Reevaluation of Menu Cost Models," Quarterly Journal of Economics, 123, 1415-1464.

Obstfeld, M. and K. Rogoff (2002): "Global Implications of Self-Oriented National Monetary Rules," Quarterly Journal of Economics, 117, 503-35.

Olivier Blanchard, I. D. C. F. And G. Adler (2014): "Can Sterilized Foreign Exchange Intervention Stem Exchange Rate Pressures from the Global Financial Cycle?" Mimeo, IMF.

Ostry, J. D., A. R. Ghosh, K. Habermeier, M. Chamon, M. S. Qureshi, And D. B. Reinhart (2010): "Capital Inflows: The Role of Controls," IMF Staff Position note SPN/10/04, February 19.

Prasad, N. (2013): "Sterilized Intervention and Caital Controls," Mimeo.

Rey, H. (2013): "Dilemma not Trilemma: The Global Financial Cycle and Monetary Policy Independence," Jackson Hole Economic Symposium, 285-333.

RotemberG, J. J. (1982): "Sticky Prices in the United States," 90, 1187-1211.

Schmitt-Grohé, S. AND M. URIBE (2003): "Closing small open economy models," Journal of International Economics, 61, 163-185.

— (2004): "Optimal Fiscal and Monetary Policy under Sticky Prices," Journal of Economic Theory, 114, 198-230.

Unsal, D. F. (2013): "Capital Flows and Financial Stability: Monetary Policy and Macroprudential Responses," International Journal of Central Banking, 9, 233-285. 
Woodford, M. (2003): Interest and Prices: Foundations of a Theory of Monetary Policy, Princeton, New Jersey: Princeton University Press. 
OPTIMAL MONETARY POLICY AND CAPITAL CONTROLS

TABLE 1. Calibrated parameters

\begin{tabular}{lll}
\hline \hline Parameter & Description & value \\
\hline$\beta$ & Subjective discount factor & 0.99 \\
$\phi_{m}$ & Utility weight on money balances & 0.06 \\
$\phi_{l}$ & Utility weight on leisure & 34.01 \\
$\eta$ & Inverse Frisch elasticity & 2 \\
$\theta$ & Elasticity of substitution between differentiated goods & 10 \\
$\psi_{1}$ & Domestic bond adjustment costs & 0.01 \\
$\psi_{2}$ & Foreign bond adjustment costs & 0.01 \\
$\psi_{3}$ & Price adjustment costs & 60 \\
$\psi_{4}$ & Slope of foreign demand for domestic bonds & 0.01 \\
$\rho_{z}$ & Persistence of technology shocks & 0.9 \\
$\rho_{r}$ & Persistence of foreign interest rate shocks & 0.9 \\
$\sigma_{z}$ & Standard deviation of technology shocks & 0.005 \\
$\sigma_{z}$ & Standard deviation of foreign interest rate shocks & 0.001 \\
\hline
\end{tabular}


TABLE 2. Macroeconomic volatilities and welfare under alternative policy regimes

\begin{tabular}{lllll}
\hline \hline & Benchmark & $\begin{array}{l}\text { No capital } \\
\text { controls }\end{array}$ & No sterilization & $\begin{array}{l}\text { Neither controls } \\
\text { nor sterilization }\end{array}$ \\
\hline$\sigma_{y}$ & 0.00553 & 0.00553 & 0.00784 & 0.00784 \\
$\sigma_{\pi}$ & 0.00260 & 0.00260 & 0.00598 & 0.00598 \\
$\sigma_{R}$ & 0.00115 & 0.00115 & 0.00053 & 0.00053 \\
$\sigma_{b^{*}}$ & 0.15919 & 0.15920 & 0.07033 & 0.07032 \\
$\sigma_{b_{f}}$ & 0 & 0.00001 & 0.00002 & 0.00001 \\
$\sigma_{b_{g}^{*}}$ & 0.21028 & 0.21029 & 0 & 0 \\
$\sigma_{\tau}$ & 0.00147 & 0 & 0.00207 & 0 \\
Welfare loss & - & 1.2304 & 2.9437 & 2.9424 \\
\hline
\end{tabular}

Note: The term $\sigma_{x}$ denotes the standard deviation of the variable $x$, where $x$ denotes aggregate output $(y)$, domestic inflation $(\pi)$, nominal interest rate $(R)$, domestic holdings of foreign bonds $\left(b^{*}\right)$, foreign holdings of domestic bonds $\left(b_{f}\right)$, foreign reserves held by the government $\left(b_{g}^{*}\right)$, and the tax rate on interest earnings by foreign investors on domestic bonds. The welfare loss under each regime is measured by steady-state consumption equivalent relative to the benchmark regime. 

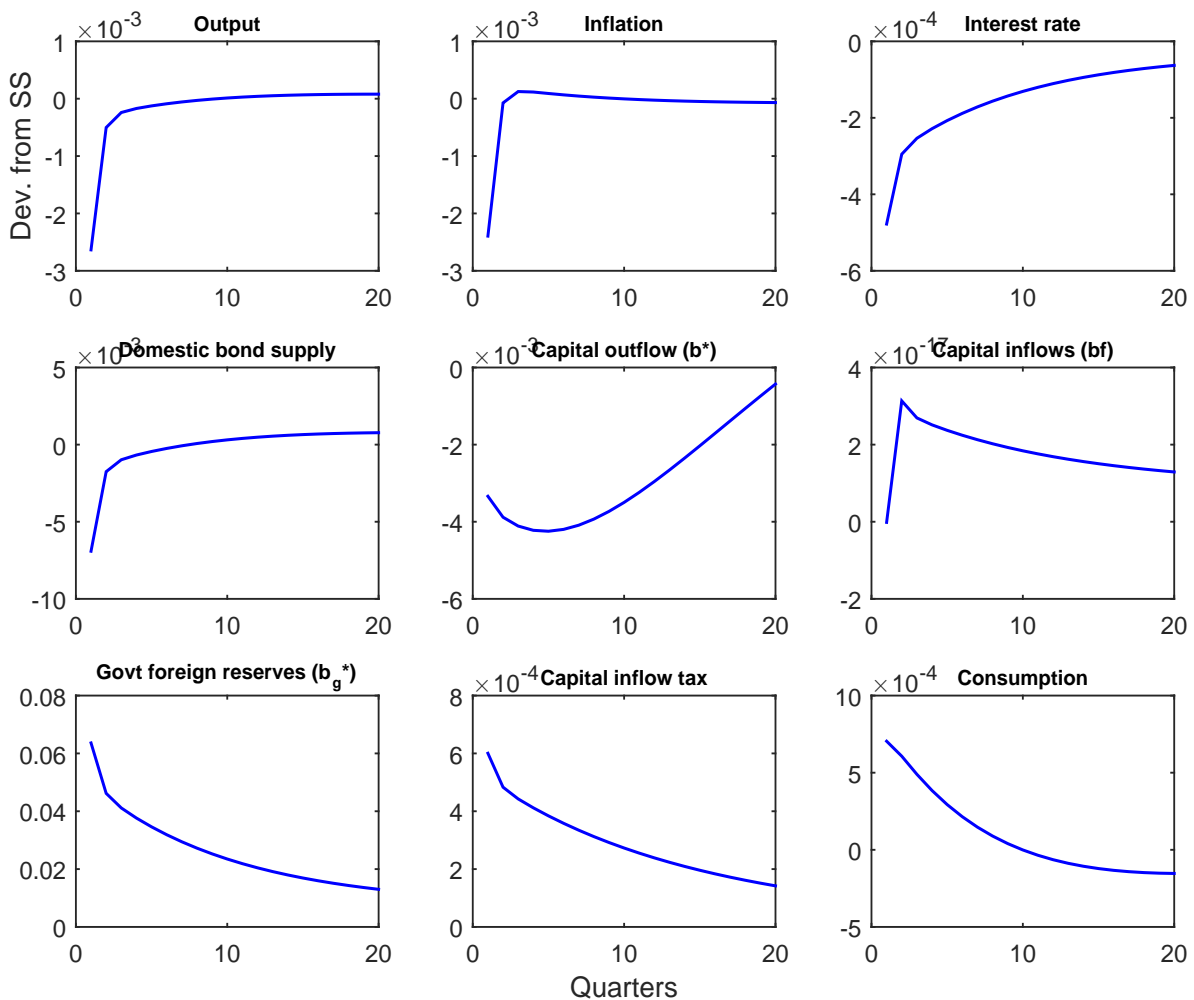

FIGURE 1. Impulse responses to a negative foreign interest rate shock under optimal sterilization and capital control policies. 

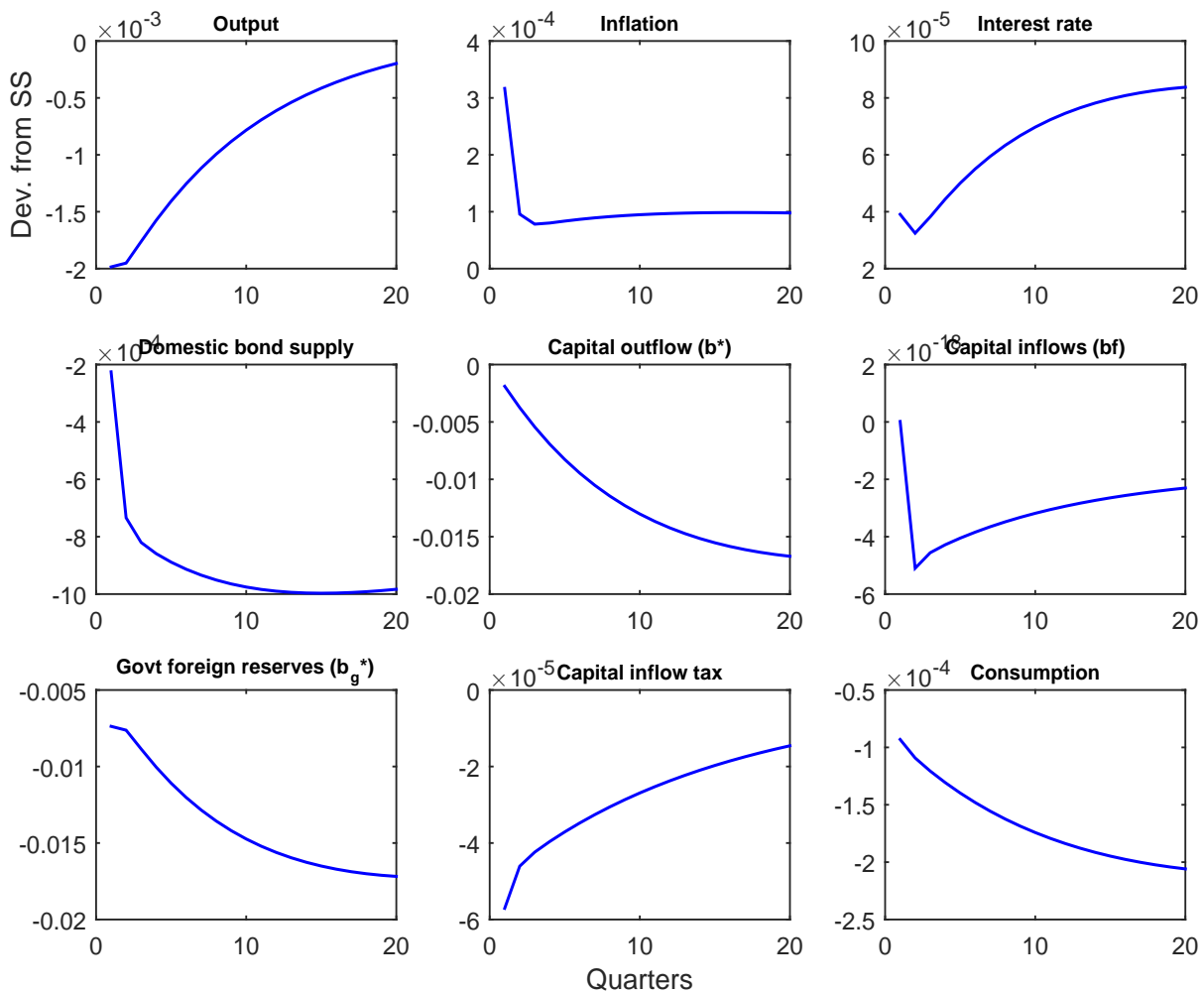

FiguRE 2. Impulse responses to a negative technology shock under optimal sterilization and capital control policies. 

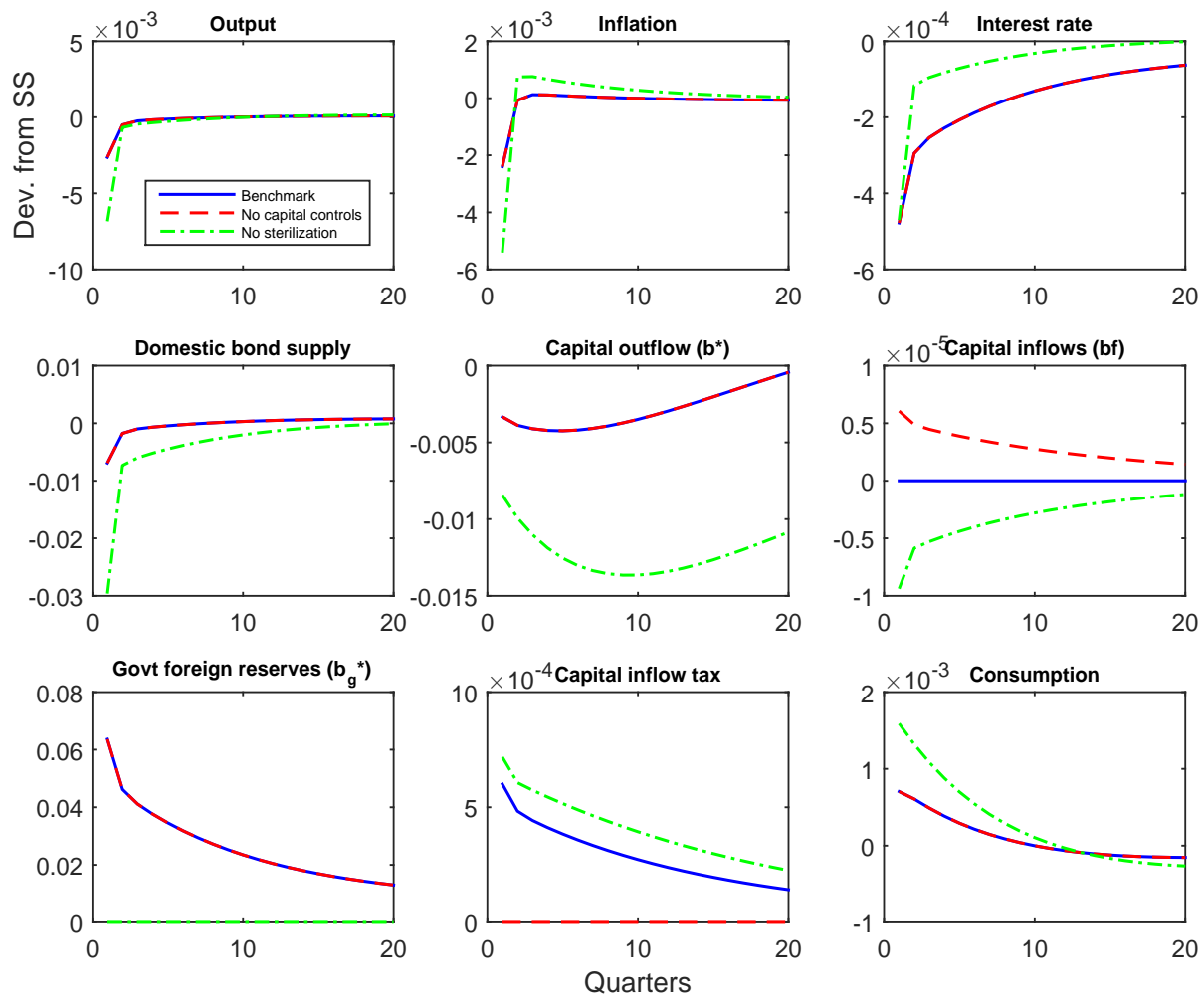

FiguRE 3. Impulse responses to a negative foreign interest rate shock under alternative policy regimes. 

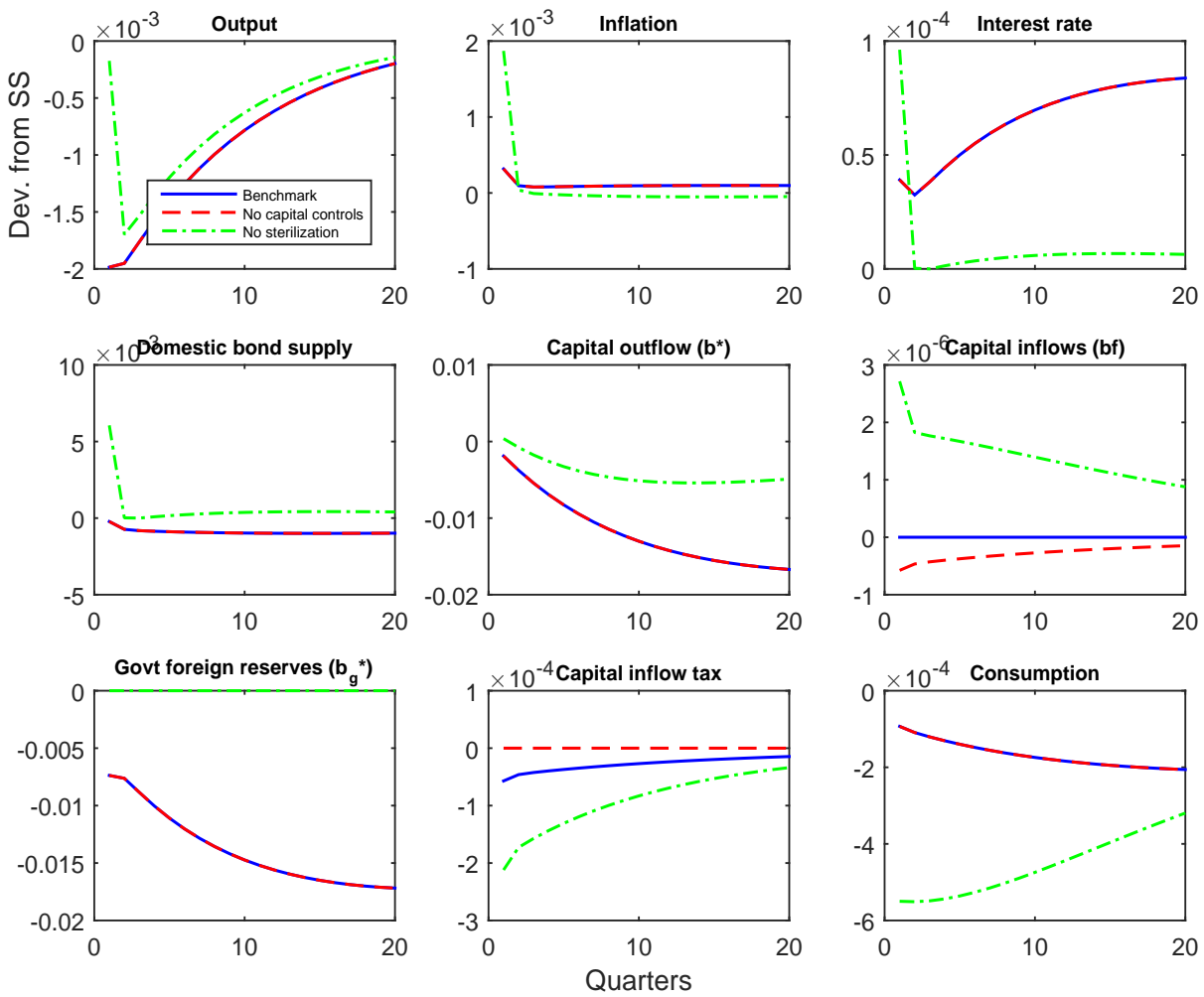

FiguRE 4. Impulse responses to a negative technology shock under alternative policy regimes. 